\title{
A magyar diplomácia újjászüiletése Afrikában Déli nyitási kísérletek a magyar külpolitikában a 19-20. században: fókuszban az 1960-70-es évek
}

\author{
The Rebirth of Hungarian Diplomacy in Africa \\ Attempts to Southern Opening in Hungarian Foreign Policy \\ in the $19^{\text {th }}$ and $20^{\text {th }}$ Centuries with the Focus on \\ the 1960s and the 1970 s
}

Solymári Dániel és Tarrósy István ${ }^{2}$ https://doi.org/10.47707/Kulugyi_Szemle.2021.4.7

Összefoglaló: A 2015-ben meghirdetett „déli nyitás” stratégiával új időszámítás vette kezdetét a magyar külpolitikában. A külügyi fókusz - egyebek mellett - a szubszaharai afrikai gazdasági kapcsolatok erősítését tűzte ki célul. 2019-ben pedig kormányzati Afrika-stratégia született, és az 1989-es magyar rendszerváltás óta abban az évben zajlott először hivatalos miniszterelnöki, 2022 ben pedig államelnöki látogatás a Szaharától délre fekvő afrikai országban. Mindez azonban messze túlmutat a magyar afrikanisztikán: közvetett módon a magyar diplomácia 1960-as és 1970-es évekbeli pragmatikus és építkező külpolitikájának a folytatása, amely az 1989-ben meghatározott külpolitikai prioritások sorában háttérbe szorult. A jelen írásunk azokat a politikatörténeti alapokat mutatja be - kiemelten az 1960-as és az 1970-es években Afrikában elért eredményekre -, amelyek megteremtették a lehetőségét az önálló, később kibontakozódó magyar külpolitikának.

Kulcsszavak: Afrika-stratégia, diplomáciatörténet, Kádár-kori külpolitika, szubszaharai Afrika, magyar külpolitika

Abstract: Launching the so-called Southern Opening Strategy in 2015, then a separate Africa Strategy in 2019, marked the beginning of a new era regarding the Hungarian government's African relations. Since the change of the political system in 1989, it was in 2019 when a Hungarian prime minister paid an official

2 Tarrósy István kutatásait az MTA Bolyai-ösztöndíja támogatta a 2018 és 2021 közötti időszakban. 
visil to a Sub-Saharan African country, followed by a presidential visit to two others in early 2022. So far, it has been scarcely documented and researched how Hungary has been fostering its engagements across the continent in the recent decades. The paper, therefore, offers an in-depth historiographical narrative of the first traces and paths of Hungary-Africa relations since the times of the dual monarchy between Austria and Hungary, but with a focus on the pragmatic development of relations since the 1950s and 1960s. It covers various archival sources of the era, which can reveal the central thesis: the continuous effort of Hungarian diplomacy to carry on the pragmatic and constructive African policies of the 1960s and 1970s, which came to a halt with the 1989 regime change.

Keywords: Africa Strategy, history of diplomacy, foreign policy in the Kádar era, Sub-Saharan Africa, Hungarian foreing policy

\section{Bevezetô gondolatok}

Az 1950-es és az 1960-as években sajátságos geopolitikai helyzet alakult ki Magyarországon. Résnyire nyílt az önálló magyar külpolitika elôtt a lehetôség, amire a kül- és belpolitikai függetlenségét veszített országban évszázadok óta nem - vagy csak alig, csupán rövidebb időre - volt példa. Magyarország akkor már a szovjet blokk tagállamaként múködött, így elvben minden küilpolitikai kérdésben a kommunista Szovjetunió akarata szerint kellett cselekednie (ahogyan az azt megelőző időkben is az éppen adott idegen hatalomnak). A magyar vezetés elsődleges külpolitikai célja az volt, hogy hazánk lekerüljön a nemzetközi közösség „feketelistájáról”, amelyre az ötvenes évek sztálinista politikája következtében kerüilt fel: újja követségeket, nagykövetségeket nyithasson a világban, kétoldalú diplomáciai kapcsolatokat alakíthasson ki, valamint tisztázza az 1956-os forradalom utáni „,magyarkérdést” az ENSZ-ben; egyúttal a geopolitikai térben növelje a gazdasági erejét és a független mozgásterét is. A magyar külpolitikát abban az időben az objektív gúzsba kötöttség jellemezte: egy olyan politikai formáció kívánt a világban szabadon mozogni (utazni, tárgyalni, megállapodni), amelynek egyrészt minden lépését előre jóvá kellett hagyatnia Moszkvával, másrészt pedig a megcélzott 


\section{Külïgyi Szemle}

nyugati (kapitalista) világ vagy „tiltott” övezetnek számított a szovjet gondolkodásban, vagy ők maguk nem kívántak közösséget vállalni a szovjetizált Magyarországgal.

Az 1960-as években azonban különleges geopolitikai helyzet jött létre: „Afrika évében” (annus mirabilis), 1960-ban, egyetlen esztendő alatt tizenhét volt gyarmati terület nyerte el a függetlenségét, Moszkva pedig nyílt konfrontációba kerüilt Kínával, addigi elsődleges és leg jelentősebb ideológiai követőjével. Ennek következtében Magyaror szág is kénytelen volt elhidegülni Kínától, a diplomáciai nyitás logikus és potenciális első számú tervezett helyszínétől, jóllehet a pekingi vezetés korábban támogatta Kádár János miniszterelnök konszolidációs kísérleteit.

Ebben az új geopolitikai szituációban a magyar külpolitika pragmatikus döntést hozott: Afrika felé fordult - a lépést pedig Moszkva nem csupán eltűrte, de támogatta is. E folyamat eredményeképpen a következő tizenöt-húsz esztendőben a magyar diplomácia felépítette a strukturális és tartalmi kereteit. Jól fedezte fel a korszak geostratégiai lehetőségeit, és - az 1920-as évek óta először - a „fekete kontinensre” lépve újrateremtette ott a teljes magyar külpolitikát.

Írásunkban azt vizsgáljuk, hogy miként zajlott le e diplomáciai nyitási kísérlet - különös tekintettel az 1960-as és az 1970-es évekbeli eseményei -, és annak milyen eredményei, hatásai lettek a honi és a nemzetközi politikai térben. Azt mutatjuk ki, hogy jóllehet a politika történeti „együttállásnak”, talán a történelmi véletlennek is köszönhe tő, de a magyar diplomácia és küilpolitika régóta vágyott füiggetlenné válása éppen afrikai kontextusban történt meg. Így napjaink déli nyitása is logikusan illeszkedik a magyar diplomáciatörténet vonalába. A kutatási fókuszterületünk újszerủnek tekinthető, ugyanis a magyar külpolitika nyitását az afrikai aspektusban még nem vizsgálták részle tesen. Munkánkban ezért döntően levéltári és más, eleddig nem küilö nösebben feltárt elsődleges forrásokra támaszkodtunk. 


\section{A magyar külpolitika útkeresése}

\section{Mozgástér és kényszerpálya}

Az ismertetett háttér mellékesnek és túlságos távolinak tűnhet a köz vetlen témánk szempontjából. A jelentősége azonban abban áll, hogy rávilágít a magyar diplomácia hosszú ideig függő, külső aktoroknak kitett helyzetére, amelyben az önálló külpolitika kialakításának nem volt realitása, és a magyar külüigyi apparátus füiggetlen mozgástérről nem is álmodhatott. De hiba lenne azt gondolni, hogy ennek a politikai vagy a diplomáciai érdektelenség volt az oka. Egy ország külpolitikájának a függetlensége nem önmagában álló lehetőség: a létrehozásának az előfeltétele a stratégiája és a prioritásai szabad alakítása.

Ha ebből a szempontból vizsgáljuk a magyar külpolitika történe tét a 18-19. századtól napjainkig, azt láthatjuk, hogy ez a függetlenség, szabad „politikaalakítás” történelmi léptékkel nézve csak pillanatokra adatott meg. Sőt, Magyarország egészen a középkor vége óta - Hunyadi Mátyás uralkodásának utolsó éveitől (1486-1490) -, később pedig a modern, vesztfáliai típusú állam kialakulásának idejétől a magyar rendszerváltásig, az első szabad parlamenti választásokig (1989-1990) jellemzően függő, alárendelt, kiszolgáltatott helyzetben volt. Folyamatos pozícióvesztés, az ország politikai és gazdasági súlyának csökkenése jellemezte ezt a közel ötszáz éves időszakot. Rövid periódusokat leszámítva (mint a két szabadságharc évei és némileg a dualizmus kora) önálló külpolitikát nem folytathatott. Szűk mozgástér és kényszerpálya: így lehet a legjobban jellemezni a Kelet és Nyugat közé szorított magyar külpolitikát, amelynek alapélménye a füiggetlenségért, a külpolitikai önállóságért vívott állandó küzdelem. A következőkben röviden elgondolkodunk a 18. és 20. század közötti időszak kapcsolódó eseményeiről, amelyek fényében kapnak majd különös jelentőséget az 1960-as és az 1970-es évek eredményei, úttörései. 


\section{Külïgyi Szemle}

\section{Magyar külpolitika a második világháború végéig}

A törökök kiűzését, így Magyarország felszabadítását követően az or szág a Habsburg Birodalom része lett (1711). A korabeli nagyhatalom pedig hazánkat jogilag független társnemzeti résznek, de alapvetỏen meghódított területnek tekintette. Jóllehet Magyarország nem olvadt be teljesen a birodalomba, bizonyos politikai önállósággal rendelke zett, de önálló külpolitikát nem folytathatott (Herczegh, 1987). Habár a magyar országgyúlés ragaszkodott ahhoz, hogy az uralkodó magyarokat is alkalmazzon a külszolgálat irányításában, csak annyit tudtak elérni, hogy az osztrák császár követei között (igaz, fontos pozíciókban) magyarok is szerepelhettek (Horváth, 1941).

1848-ra küszöbön állt a Habsburg Birodalom felbomlása. A magyar reformerek függetlenségre törekedtek, míg mások továbbra is szupranacionális kereteken belül kívántak maradni. Habár a korábbi évtizedek külügyi képzése és külszolgálata eredményeképpen számos sikeres és nemzetközileg is elismert magyar diplomatáról tudunk, mint például Esterházy Pál vagy Apponyi Antal, a magyar politikai elit egységes és kiforrott külpolitikával nem rendelkezett.

A poroszoktól elszenvedett vereség hatására Ausztriának megegyezésre kellett jutnia Magyarországgal: megtörtént a kiegyezés, létrejött az Osztrák-Magyar Monarchia, amelyben a felek az állami funkciókat parlamentáris alkotmányos monarchiában, közösen gya korolták. A dualizmus időszakában önálló belpolitika és gazdaság múködött, a külügy azonban osztatlan maradt. 1867-ben létrejött a közös külügyminisztérium, élén a közös küllügyminiszterrel. E poszton 1918 ig összesen tizenegyen váltották egymást, közülïik három volt magyar nemzetiségú (Hajdú, 1967, 460. o.; Győri Szabó, 2011). Az 1867. évi „kvótamegállapodás” értelmében a külügyi hivatalok viselésében a magyar állampolgárok aránya kezdetben 26, később 32 százalék volt.

1918-ban a Monarchia felbomlott, Magyarország elnyerte szuvere nitását. Megszületett az önálló küllügyi igazgatás, amelyről az 1918. évi V. néptörvény kimondta, hogy az ország ,minden külüigyét önállóan intézi" (Nel.jogtar, é. n.). Magyarország újkori, füiggetlen külpolitikájának 
időszámítása ekkor vette kezdetét. Az első világháborút és a párizsi békekonferenciát követő években az első számú külügyi feladat az állam új határainak a kérdése volt: Magyarország súlyos területi veszte ségeket szenvedett el, így az össznemzeti fókuszban a békeszerződés revíziója állt. Más küilügyi célnak így nem volt realitása.

1930 -ra azonban az önálló útját járó magyar diplomácia újjászervezte a külüigyi igazgatást: új külüigyminisztérium jött létre, megte remtették a saját külügyi képzést, széles európai követségi hálózat alakult ki, immáron Európán kívüli képviseletekkel is. Az első ilyen az afrikai kontinensen az egyiptomi követség megnyitása volt.

A két világháború közötti időszakban az ország elszigetelődött, a nemzetközi kapcsolatai a minimumra csökkentek. Akárcsak a 19. században, ismét csak követek küldésére volt jogosult (Győri Szabó, 2011, 65. o.), nagyköveteket nem nevezhetett ki. A külpolitikai szövetségesek keresése titkos diplomáciával történt: a nagyhatalmak és a semleges államok egy vesztes állammal nem kívánták diszkreditálni magukat a nemzetközi térben. A külüigyi mozgástér így ismét beszúkült.

A második világháborút követő koalíciós időszak ismét kényszer pályára állította a magyar külpolitikát: vesztes félként a működését a Szövetséges Ellenőrző Bizottság (SZEB) korlátozta, a külügyi kér désekben, az új diplomáciai kapcsolatok felvételében pedig a SZEB szovjet vezetése döntött. Magyarország függetlensége újra megszűnt.

\section{Szovjel külpolitika Magyarországon}

A kommunista hatalomátvétel után alapjaiban változott meg az or szág külpolitikája. Magyarország a szovjet befolyási övezet része lett, tulajdonképpen egy szovjet tagköztársaság szintjére süllyedt. Viharos gyorsasággal szovjetizálódott a szuverenitását veszített államhata lom: megszúnt a parlamentarizmus és a többpártrendszer, létrejött a pártalapú diktatúra, a diplomáciai tér bezárult. A külpolitika elsődleges alakítója Sztálin lett, aki az egyes országok állampártjának a fótitkárait a Szovjetunió Kommunista Pártjának (SZKP) külügyi osztályán keresztuil irányította. Nálunk Rákosi Mátyás pártfőtitkár - később a 


\section{Külïgyi Szemle}

Magyar Népköztársaság Minisztertanácsának elnöke - és Gerő Ernő alakította a „magyar külpolitikát”. Önálló lépéseik nem voltak: a Külügyminisztérium, a külügyi igazgatás, a diplomácia csak formálisan működött, jellemzően a Moszkvából kapott utasításokat hajtották végre. Ahogyan Romsics Ignác fogalmazta meg: „egyetlen lehetősége a "tábor "többi csatlós államához hasonlóan a szovjet irányvonal követése volt" (Romsics, 2003, 338. o.). Amint pedig azt Békés Csaba állapította meg: „a magyar külpolitika a szovjet-magyar viszony terén a konstruktív lojalitás politikájának érvényesítésére törekedett. Ennek a magatartásnak a fő jellemzői egyfelől a konfliktuskerülés - elsősorban a politikai kérdések terén -, rugalmasság és folyamatos alkalmazkodás a szovjet igényekhez, kooperációs hajlandóság" (Békés, 2004, 136. o.). A külügy nemzetközi keretét a sztálinizmus rendszere, hálózata adta: a magyar-szovjet barátsági, együttműködési és kölcsönös segélynyújtási szerződés (1948), valamint a Kölcsönös Gazdasági Se gítség Tanácsa (KGST), később pedig az európai szocialista országok úgynevezett ,védelmi katonai-politikai szervezete”, a Varsói Szerző dés (1955). A hidegháborús események tovább szűkítették Magyaror szág számára a diplomáciai mozgásteret: a küilföldi utazás lehetősége megszűnt vagy minimálisra csökkent (nyugati utazást lehetővé tevő útlevelet nehezen vagy egyáltalán nem lehetett szerezni), a levelek küldését is limitálták; az ország küilkapcsolatai a „vasfüiggönyön túli” érdekszférával ellenségessé, konfliktusossá váltak. A nyugati követsé geink, diplomáciai misszióink csak formálisan működtek.

Mindezzel együtt az 1950-es évekre a politikai és a küilgazdasági kapcsolatok dinamikusabbakká váltak: az elsősorban keleti irányba fordult magyar külpolitika kereste az új partnereket, a kétoldalú megállapodásokat. Egy új nyitásnak tekinthető ez az időszak, amelynek az egyik legjelentősebb diplomáciai lépéseként Magyarország az elsők között ismerte el a Kínai Népköztársaságot, és 1949-ben újranyitotta a követségét Pekingben. Kínával ennek ellenére sem indulhattak meg a dinamikus kétoldalú kapcsolatok, jóllehet logikusnak tűnhet, hogy a küilkapcsolatait építő magyar diplomácia először a kommunista tömbön belül keresett partnereket. Ennek elsősorban nem sajátságosan 
magyar okai voltak (mint az ENSZ-szel vagy a nyugati államokkal való kapcsolat esetében), sokkal inkább geopolitikai.

A két világháború között nem létezett közvetlen magyar-kínai re láció, az akkori szövetségi rendszerből adódóan Magyarország Japán nal volt kapcsolatban. 1949-tôl a hazai diplomácia a szovjet politikát követte: amikor ôk jobb kapcsolatban voltak Pekinggel, akkor Budapest is, ha nem, akkor az utóbbi sem. Ennek ellenére a szovjet külpolitikával való azonosulás sosem volt maradéktalan, és Moszkva is hagyott némi mozgásteret a Külüigyminisztérium számára. Kádár János ezt ki is használta, és Peking szimpatizált az útját kereső Magyarországgal (Vámos, 2017, 47-45. o.). 1960-tól azonban Kína és a Szovjetunió nyílt konfliktusban állt egymással, és szovjet nyomásra a magyar vezetés is kénytelen volt elhidegülni Pekingtől. Az 1966-ban kitört kulturális forradalom után pedig a kapcsolat a minimálisra esett vissza. A kínai vezetéssel való viszonylag dinamikusabb kapcsolat csak 1978-tól, a tengi reformok meghirdetésétől kezdődhetett újra, ami már némileg egy, a szovjet „pályától” való eltérést eredményezett. Mindez azt a sajátságos geopolitikai helyzetet eredményezte, hogy Magyarország külügyi reményekkel tekinthetett Afrika irányába, és e pragmatikus külpolitikai nyitást a szovjet vezetés sem gátolta.

\section{A magyar küilpolitika elsố nyitási kísérletei}

Sztálin 1953-ban bekövetkezett halála után a szovjet külpolitika is kereste az enyhülés lehetôségeit - miközben a blokkon belül megmaradt az elvárás: „a mindenkori moszkvai képlethez való igazodás” (Gyarmati, 2013, 330. o.). Az SZKP új elsô titkára (később a Minisztertanács elnöke), Nyikita Szergejevics Hruscsov a harmadik világ felé is nyitott, továbbá célul túzte ki az el nem kötelezett országok mozgalmának az erősítését. Az 1955-ben megtartott bandungi konferencián meghir dették a Dasa Silát [tíz előírás], amely többek között a békés egymás mellett élés alapelvét is tartalmazta - e külpolitika egyszerre haladt pragmatikus és ideológiai síkon. 


\section{Külïgyi Szemle}

Az 1956-os budapesti forradalmi eseményeket követő „diplomáciai karantén" után, az 1960-as évekre Magyarországon enyhültek az utazási korlátozások: a szocialista blokkon belül vízummentesen lehetett mozogni (Magyar Nemzeti Levéltár, 1956a), lazultak a hivatalos küiföldi utazások szabályai is (Magyar Nemzeti Levéltár, 1957a). A nyugati országok jelentős része kezdetben illegitimnek, később „csak” szalonképtelennek tartotta a Kádár János vezette magyar kormányt, ezért a diplomáciai kapcsolatokat a minimumon tartották. Budapestnek emiatt jól belátott érdeke volt, hogy kompenzáljon, más irányba keresse a nemzetközi elfogadottságát, a külgazdasági kapcsolatait és az ideológiai szövetségeseit. Megtörténtek az első jelentős, már nem kizárólag európai irányú kitörési kísérletek: közel kilencven új diplomáciai kapcsolat létesült, illetve emelkedett nagyköveti szintre afrikai, ázsiai és latin-amerikai országokkal, ami azt igazolja, hogy Kádár a nagyfokú nemzetközi elszigeteltségen részben úgy igyekezett enyhíteni, hogy kapcsolatokat épített ki a „harmadik világ szovjetbarát, illetve el nem kötelezett országaival” (Romsics, 2003, 512. o.).

\section{Külpolitika Sztálin halála után}

A magyar küilpolitika újraéledése az 1950-es években vette kezdetét. Sztálin halála után nyitottabb, racionálisabb szovjet küilügyi gondolkodás alakulhatott ki. Utódja, Nyikita Szergejevics Hruscsov a sztálinizmustól való elszakadást sürgette; enyhüilést, az izoláltságból való kitörést, a világra nyitottabb diplomáciát. Így új kapcsolatok jöttek létre a szocialista relációban is, amihez azonban először a nemzetközi közösség bizalmát kellett megnyerni.

A Rákosi Mátyás által irányított Magyarországnak ez nem volt könnyű, ugyanis az 1940-es évek végére, az ötvenes évtized elejére a második világháborúból vesztesen kikerült ország szovjetizált övezetté vált, a Nyugattal állandó konfrontációban állt. A bilaterális együtt múködések egysíkúak voltak, az ország gazdaságilag kimerült; a nyu gati viszony ellenségessé vált: a kölcsönös kiutasítások folyamatosak 
lettek, s végüil be is fagytak a kapcsolatok. 1949-ben az ország ENSZ tagsága meghiúsult, és azon nemzetközi szervezetekben is csökkentette a szerepvállalását, amelyekben a nyugati államok tagsággal ren delkeztek (1950-ben kilépett a WHO-ból is).

Az 1956-os forradalom leverését követő megtorlás után sem szűnt meg a szovjet befolyás. Kádár a Magyar Népköztársaság Miniszter tanácsának elnöke (kormányfő) lett. Hruscsov számára „mintatanít vánnyá”, Magyarország pedig a blokk egyik élharcosává vált. Győri Szabó Róbert erről így fogalmazott: „1957 és 1964 között a Hruscsov vezette Szovjetunió dinamikus, kezdeményező, önbizalomtól duzzadó külpolitikát folytatott. ... Szövetségeseivel kooperatívabb, rugalmasabb lett, enyhített a csatlósok teljes alárendeltségén" (Győri Szabó, 2011, 270. o.). Magyarországon a hatalmat az állampárt birtokolta, és azt a Magyar Szocialista Munkáspárt (MSZMP) szilárdan kézben tartotta. Külügyi kérdésekben az MSZMP Politikai Bizottsága döntött, a dön tés-előkészítést a Központi Bizottság Külügyi Osztálya végezte, és a küilügyekért felelős titkár felelt érte.

Kádár nemzetközi ügyekben nyitott, érdeklődő volt, az 1960-as évek elejére már pragmatikus külpolitikát folytatott. Hitt a nyugati kapitalista és a szocialista világrend közötti küzdelemben, de új politikai és gazdasági rendszerét már tárgyalásos, építkező módon kívánta létrehozni. A külpolitikai törekvéseit 1966-ban, az MSZMP IX. kong resszusán ismertette: békés egymás mellett élés, egyetemes béke, a gazdasági és kulturális kapcsolatok fejlesztése, a harmadik világ felszabadító mozgalmainak a támogatása, együittműködés a függetlenné vált államokkal (Magyar Tudomány, 1967). Puja Frigyes, aki közel 10 évig (1973 és 1983 között) töltötte be a külügyminiszteri posztot, így magyarázta a proletár internacionalizmus lényegét: „a Magyar Nép köztársaság külpolitikájának alapelve a különböző társadalmi rend szerú országok békés egymás mellett élésének elve; olyan államközi viszony, melyben a felek lemondanak a háborúról, tiszteletben tartják egymás szuverenitását, kétoldalú kapcsolataikban mindezt általános normának tekintik" (Puja, 1980, 55. o.). 


\section{Külïgyi Szemle}

A külügyi tárca súlya és jelentősége megnövekedett, és olyan felkészült szakemberek is részét képezték az adminisztrációnak, mint a három külügyminiszter: a korábbi református püspök, Péter János; az egykori piarista diák, jogász, karrierdiplomata (és afrikanista) Sík Endre; illetve Puja Frigyes, aki előzőleg nyugati országokban töltött be követi posztot. Kádár azonban a külpolitika valódi irányítását mindvégig a saját kezében tartotta, és a „sikeres politizálás alapvető terrénumának" tekintette (Pritz, 2006, 34. o.).

\section{A külkapcsolatok szocialista úttörối Afrikában}

Az afrikai országokkal való külkapcsolatok fejlesztését elsődleges célként fogalmazta meg Kádár az MSZMP 1967-es konferenciáján elmondott beszédében: a proletár internacionalizmus szellemében „fejlesztjük együttmúködésünket Afrika ... füiggetlen államaival, küzdüink a békés egymás mellett élés megvalósításáért" - összegezte terveit (Puja, 1980, 62. o.). E kifejezetten nyitott szemléletű, kezdeményező külpolitika mögött azonban egyrészt politikai pragmatizmus, másrészt a kommunista tömb szemléletpolitikája állt. Történelmi párhuzam, az események együittes alakulása, hogy a szubszaharai Afrika számos, újonnan függetlenné vált országa éppen a szovjet blokk külpolitikai irányváltásával egy időben kereste a saját útját, építette ki a gazdasági és adminisztrációs kereteit. Egyesek nyitottak voltak a szocialista eszmékre, és elfogadták a tömb országai által felajánlott (döntően ideológiai) segítséget. A több fekete-afrikai országban is végbement 1960-as évekbeli változásról John Donelly Fage és William Tordoff így írt: a füiggetlenné vált országokban

„gyors elmozdulás történt a pluralizmustól a hatalom centralizációja felé (a hatalom rendszerint egyetlen párt kezében összpontosult). Mindez együitt járt az államelnöki posztot be töltő pártvezető személyes hatalmának kiépülésével és egyfajta szocialista szemlélet megjelenésével. Mindössze azonban nyole afrikai ország hirdetett meg hivatalosan szocialista kor mányprogramot. Az 1970-es évekig alig néhány afrikai vezető vallott ortodox marxista nézeteket. Ők a marxizmust és más 
eszméket az afrikai viszonyokhoz igazították. Az afrikai szo cialista ernyő olyan széles volt, hogy még a kapitalista típusú politikát követő kenyai és szenegáli vezetők is befértek alá." (Fage-Tordoff, 2004, 423. o.)

Ahogy azt Benkes Mihály jelzi: „az első generációs afrikai politikusok ösztönösen, majd tudatosan is antikapitalista alternativákat kutattak... Mindannyian a »kizsákmányolásmentes társadalom « célkitűzését tartották megfelelő tájékozódási iránynak” (Benkes, 2006. 26-33. o.).

Az 1970-es évekre ez a „térkép” tovább bővült, és számos helyen - például az egykori portugál gyarmatokon vagy Szomáliában, Etiópiában és Tanzániában is - egyértelműen marxista rendszerek kerültek hatalomra. Jóllehet voltak olyan afrikai vezető politikusok, akik való ban hittek a szocializmusban (mint Kwame Nkrumah, Julius Nyerere, Léopold Sédar Senghor és Abdou Diouf vagy Henry S. Meebelo), a többség inkább egyfajta progresszív, a kolonialista múlttal élesen szakítani képes eszközt látott benne. Az afrikai függetlenedés egyik ikonikus alakja, a ghánai Nkrumah „a hatvanas évek elejéig sokszor marxistaként, utána pedig marxista-leninistaként definiálta önmagát" (Búr, 2011, 125. o.). Szakítani kívántak azzal az európai szemlélettel, amelyet mások mellett Harry Hamilton Johnstone vagy Eric Stokes, a Pax Britannica szellemében így fogalmazott meg: "Africa must be ruled by whites, developed by Indians and worked by blacks" (Meebelo, 1986, 3. o.), azaz magyarul: „Afrikát a fehéreknek kell uralniuk, mi közben az indiaiak hajtanak végre fejlesztéseket, és a feketék dolgoz nak”. Ebből a ,johnstoniánus” filozófiából (korabeli mondással a „white aristocrats, yellow middle class and black proletariat" [fehér arisztokraták, sárga középosztály és fekete proletáriátus]) nőtt ki az afrikai proletáriátus, és kereste útját az önállósodás felé. Az afrikai baloldal motivációja így az volt, hogy önálló célokkal ötvözött „nem kapitalista” utat járjanak. Ehhez azonban nem rendelkeztek megfelelő saját ideológiai és politikai eszközökkel. A kapitalista, gyarmati múlt emlékeit idéző jövő viszont elfogadhatatlan volt számukra. 


\section{Külïgyi Szemle}

Kádár, akinek az MSZMP egyes kongresszusain elhangzott programbeszédei világos külpolitikai irányt mutattak, ebbe az ívbe illesztette be a szintén építkező, útját kereső magyar külpolitikát. E gondolatot részleteiben is megismerhetjük Puja Frigyesnek az 1969-ben kiadott Egység és vita a nemzetközi kommunista mozgalomban, majd az 1980-ban publikált (korábban már hivatkozott) Magyar külpolitika címú könyvén keresztüil. A ,proletár internacionalizmus és a békés egymás mellett élés" a kádári diplomácia elsődleges külpolitikai alapelve volt. A szocialista világban Kádár olyan erőt látott, amely a szocialista orientációjú egykori gyarmati országok számára eszközül szolgálhat az államépítésükhöz (Puja, 1980, 50. o.). Támogatta „a nemzeti felszabadító mozgalmak harcát a régi és új gyarmatositás, imperialista elnyomás ellen”, és „fejleszteni kívánta együttmúködését Afrika független országaival” (Puja, 1980, 62. o.).

A kínai és a kubai folyamatokhoz kapcsolódva - kezdetben indirekt módon - ezt a "harcot” igyekezett Kádár segíteni a Dél-afrikai Köztársaságban, Angolában, Namíbiában és Mozambikban is. Mindezt így összegezte az MSZMP XII. kongresszusán: „Afrikában kivívták függetlenségüket Angola, Mozambik, a volt portugál gyarmatok népei. Sikeresen halad előre a maga választott útján Etiópia, s legutóbb - sokéves küzdelem után - jelentős győzelmet értek el a zimbabwei hazafiak" (Puja, 1980, 99. o.).

Magyarország és a fejlődő országok - azon belül is a szubszaharai Afrika - kapcsolata különös hangsúlyt kapott az 1960-as évek honi külpolitikájában. Ezen államok körét akkor így definiálták: ,fejlődő országoknak nevezzük azokat a gyarmati uralom alól felszabadult afrikai, ázsiai és latin-amerikai országokat, amelyek kivívták függetlenségüket, önálló nemzeti kormányuk van, de gazdaságilag, társadalmilag és egyéb téren még viselik gyarmati-félgyarmati múltjuk következményeit" (Puja, 1980, 101. o.). E területeket Kádár potenciális partnere inek tekintette, a magyar diplomácia új stratégiai irányainak. Közüilük is kiemelt helyet foglaltak el a terveiben Fekete-Afrika országai (elsősorban Kelet-Afrika és a volt portugál gyarmatok), amelyeket a nemzetközi osztályhare meghatározó szereplőinek, az imperializmus 
(és a neokolonializmus) elleni küzdelemben hazánk természetes szövetségeseinek látott. Ebben a szemléletben kezdte megtenni az első, önálló diplomáciai lépéseit az 1950-es években.

\section{A Kádár-kori diplomácia nyitása}

Kádár legfőbb diplomáciai célja az volt, hogy a magyar külpolitikát el fogadtassa a nemzetközi térben, s szakítson az ötvenes évek (és az azt megelőző) elszigetelt, páriaállapotával, és fejlessze az ország gazdasági kapcsolatait. Mindezt pragmatikus, megfontolt küilpolitikai esz közökkel kívánta elérni. „Arra törekedett, hogy ez a vetélkedés békés úton, politikai, gazdasági és ideológiai versenyben dőljön el. Az ideológiát illetően hitt a szocializmus fölényében, politikai-katonai téren erőegyensúlyt látott, egyedüil gazdasági tekintetben érzékelt jelentős lemaradást, ezért erre a területre igyekezett összpontosítani” (Győri Szabó, 2011, 277. o.). E terv megvalósítása érdekében 1956-ban, illetve 1957-ben megtalálták az első (régi-új) szimbolikusnak is tekinthető kitörési pontokat - előbb Egyiptom és Szudán, majd egymásutánban további számos szubszaharai afrikai ország felé.

Egyiptommal - ahogy ezt korábban részletesebben is kifejtettük hagyományosan jó diplomáciai kapcsolatai voltak Magyarországnak. Már a második világháborút követően megtörtént a reláció megújítása, majd 1947. december 20-án a követség felállítása. Horváth Imre küilügyminiszter (korábban berlini, londoni, majd prágai nagykövet, az 1957-es második magyar ENSZ-delegáció vezetője) 1957 áprilisában előterjesztést nyújtott be a Minisztertanácsnak (kormánynak) a Magyar Népköztársaság kairói követségének a nagykövetségi rangra emelésével kapcsolatos tárgyalások megkezdéséről. Az előterjesztés így szólt: „A két ország között kialakult baráti kapcsolatok elmélyítése céljából szükséges, hogy követségeinket kölcsönösen nagykövetségi rangra emeljuik. Ez a kérdés még 1956. október 23-a elött felmerüilt, azonban a közbejött események miatt megtárgyalására nem kerülhe tett sor" (Magyar Közlöny, 1957). A Kádár vezette (első) Magyar For radalmi Munkás-Paraszt Kormány még abban az évben döntött az 


\section{Külïgyi Szemle}

1947-ben újranyitott követség nagyköveti rangra emeléséről (Magyar Nemzeti Levéltár, 1957b).

A késóbbi ENSZ-nagykövet, Szarka Károly külügyminiszter-he lyettes vezetésével 1957 augusztusában kormányküildöttség utazott Egyiptomba. Az ENSZ őszi ülésszaka előtt tett látogatás elsődleges célja az volt, hogy a New York-i magyar delegáció számára támogatást szerezzen a „magyarkérdésről” szóló vitában (vö. Békés és Kecskés, 2006). Augusztus 29-én Gamel Abden-Nasszer elnök a rezidenciáján fogadta a magyar delegációt, ahol kiemelten az ENSZ-szel és az Ötös Bizottsággal kapcsolatban folytattak eszmecserét. A feljegyzések szerint Nasszer így fogalmazott a találkozón: „A nyugati hatalmak a magyarkérdést propagandára használják fel az ENSZ-ben, mégpe dig elsősorban a Szovjetunió ellen. Közölte, hogy Egyiptom és Szíria támogatását biztosra vehetjük" (Újvári, 2017, 61. o.). Az út e szempontból tehát eredményes volt: Egyiptom és az arab országok egy része a következő öt évben, amíg a „magyarkérdést” az ENSZ vizsgálta, a magyar kormány mellett szavazott.

Még ugyanabban az évben viszonzó látogatásra is sor került: egyip tomi parlamenti delegáció látogatott Magyarországra. Az itteni megbeszélések során már katonai, gazdasági, kulturális, mezőgazdasági és kereskedelmi témák is napirendre kerültek. Az eseményről a magyar sajtó is gazdagon tudósított: a napilapok részletesen, képekkel illusztrálva ismertették Abdel Fattah el-Bindarinak, Kairó kormányzójának a Budapest Főváros Tanácsánál tett látogatását (Esli Hirlap, 1957a) vagy Mustafa Khalil közlekedésügyi miniszter útját, aki az egyiptomi megrendelésre gyártott magyar dízelvonaton utazott Hegyeshalomból Győrbe (Esti Hirlap, 1957b).

A kor másik jelentős diplomáciai lépése az afrikai relációban Etiópia irányába történt. Ez nem az első eset volt, ugyanis - ahogy azt Szélinger Balázs is megállapította - az Osztrák-Magyar Monarchia és Abesszínia között a diplomáciai kapcsolatok felvétele már 1905 ben elkezdődött, bár az akkori lépések csak előzménynek tekinthe tőek, és jellemzően informálisak maradtak (Szélinger, 2008, 27. o.). E kapcsolatok csak a második világháborút követően dinamizálódtak 
újra, és érték el a személyközi relációkon túli szintet. Marsai Viktor az erről írt összegző munkájában úgy fogalmazott, hogy a „világháború után formálódó új nemzetközi rendszerben a szovjet megszállás első évei, az újjáépítés és a szocializmus erőltetett kiépítése szintén minden energiát lekötöttek, és az eleve korlátozott külpolitikai lehetőségek között Etiópia nemhogy elsőbbséget nem élvezett, de figyelem is alig fordult felé" (Marsai, 2020, 48-66. o.). Többévnyi tapogatózó és előkészitő munka (valamint szovjet támogatás) után a diplomáciai kapcsolatok felvételére végül 1959-ben, a nagyköveti szint kialakítására pedig csak 1964-ben kerüilt sor.

A magyar sajtóban visszatérő témák lettek a „fejlődő világot” érin tő kérdések. A Szabad Nép, később a Népszabadság, a Pesti Hírlap, az Esti Hirlap, Az Esl és más lapok heti szinten tudósítottak az arab világot érintő honi vonatkozású és külpolitikai kérdésekről. A relációban a kapcsolatok megújultak, felélénkülttek (az 1945 előtti állapotokhoz hasonlóak lettek). Nyugati diplomaták - például a Budapesten állomásozó francia követ - „Kelet-járásról” és „kereskedelmi offenzíváról” írt a jelentésében (J. Nagy, 2017, 47. o.).

\section{Magyar elsóség Szudánban}

1956. január 1-jén Szudán kikiáltotta a függetlenségét, s azt Hege düs András, a Magyar Népköztársaság Minisztertanácsának elnöke - a szudáni képviselőház 1955. december 19-én hozott határozatához kapcsolódva - 1955. december 30-án minisztertanácsi határozatban ismerte el (Magyar Közlöny, 1956a). Az afrikanista-diplomata Sík Endre (korábban washingtoni magyar követ és a Külügyi Akadémia igazgatója) külügyminiszter-helyettes által jegyzett előterjesztés így indokolta a döntést:

„új szuverén állam, a Szudáni Köztársaság jött létre. A nemzet közi jog szerint az új állam más államok elismerése nélküil jön létre, de a nemzetközi kapcsolatok felvételéhez szüiksége van más államok elismerésére. A szudáni kormány tehát feltehetően a Magyar Népköztársaság elismerését is kérni fogja. A Ma gyar Népköztársaság üdvözli a Szudáni Köztársaság létrejöttét, 


\section{Külïgyi Szemle}

mert ez a tény a gyarmati népek szabadságtörekvéseinek újabb sikerét, s a nemzetek önrendelkezési jogát hirdető nemzetközi jogi elvnek - amelyet különben az Egyesüllt Nemzetek Alapokmánya is elismer - újabb győzelmét jelenti" (Magyar Nemzeti Levéltár, 1956b).

Az új állam elismerését hamarosan a diplomáciai kapcsolatok fel vételéról szóló határozat követte: a Magyar Népköztársaság az euró pai államok közül elsőként állított fel követséget Kartúmban, és ne vezett ki követet 1956. március 7-én (Magyar Közlöny, 1956b; Magyar Nemzeti Levéltár, 1956c). A magyar napilapok teljes terjedelmében mutatták be Hegedüs András Ismail al-Azhari szudáni miniszterelnöknek írt táviratát (Esti Hirlap, 1956; Magyar Nemzet, 1956a; Népszava, 1956a), majd annak válaszlevelét (Esti Budapest, 1956).

1956 májusában, a diplomáciai egyezmény megkötését követően, Ibrahim el-Mufti szudáni kereskedelmi miniszter Budapesten tárgyalt Hegedüs Andrással. A találkozót a magyar sajtó újfent gazdagon dokumentálta, és egy, az afrikai politikussal készült hosszú interjút is közölt (Népszava, 1956b). A szudáni miniszter így nyilatkozott a magyar-szudáni kereskedelmi kapcsolatok kiszélesítéséról:

„Szudán a világ legtöbb országával kereskedik. Nem teszünk megkülönböztetést egyetlen nemzettel sem; eladjuk áruinkat azoknak, akik a legjobb árat fizetik, és vásárolunk azoktól, akik a legjobb minőségű árut a legolcsóbban adják. Békeszerető nép vagyunk, és békében, s jó viszonyban akarunk élni minden országgal. Szeretjük mindazokat, akik szeretik a békét. Üdvözöljük a magyar és szudáni gazdasági kapcsolatok kiszé lesítését, és szívesen fogadjuk a gazdasági segítséget, ha nem jár politikai feltételekkel" - fogalmazott a miniszter (Magyar Nemzet, 1956b).

E gondolatban megfigyelhető az „afrikai szocializmus” pragmati kussága és a saját útjukat kereső afrikai népek politikai-gazdasági ars poeticája. A nyitottságuk valós igényből táplálkozott, amellyel kapcsolatban a Külkereskedelem címú folyóirat 1957. novemberi száma így tudósított: 
„A szudáni szóvivő kijelentette, hogy mivel a nyugat nem ér deklődik eléggé a szudáni gyapot iránt, a kormányzat kénytelen más piacokhoz fordulni. A szovjet ajánlat a gazdasági kapcsolatok kiépítésére igen kedvező, mert hajlandó szudáni termékeket keményvaluta ellenében megvásárolni, széles körú árucsere-forgalmi egyezmény keretében hosszúlejáratú hitelt rendelkezésre bocsátani és a szudáni ipar kifejlesztéséhez múszaki tanácsokat küldeni” (Külkereskedelem, 1957, 16. o.).

A magyar-szudáni kapcsolatoknak akkoriban még nem volt számottevő eredményüik; sokkal inkább a közeledés, a kölcsönös építkezés jellemezte. Ennek az egyik oka az volt, hogy a szudáni kormány is a helyét kereste a nemzetközi térben. Erre vonatkozó utalás a Minisztertanács 1958. szeptember 5-én kelt jegyzőkönyvében is megfigyelhetô, amely szerint

„[a] szudáni kereskedelmi tanácsosunk f. hó 4-én táviratilag közölte, hogy a szeptember hó 7-14-ig tartó lipcsei vásárra utazó szudáni kereskedelmi miniszter - amennyiben meghí vást kap - hajlandó Magyarországra látogatni... Látogatásá nak nincs előre meghatározott célja, fel kívánjuk venni vele a kapcsolatot, és egyrészt lehetőséget kívánunk biztosítani rajta keresztül a szudáni piacon erósen érvényesülő importkorlá tozásokkal szemben a magyar könnyúipari fogyasztási cikkek bevitelének fokozott engedélyezésére, másrészt célunk, hogy itt-tartózkodása alatt elvigyük üzemlátogatásokra, megmutas suk ipari hátterünket, és felhívjuk figyelmét állami megrende lésekkel kapcsolatos nehézipari szállításainkra” (Magyar Nem zeti Levéltár, 1958a).

Közel kétéves előkészitést és diplomáciai építkezést követően, 1958. április 29-én - a moszkvai utazását rövid időre megszakítva Budapestre látogatott Gamel Abden-Nasszer, az Egyesült Arab Köz társaság elnöke, akit kormánya több magas rangú politikusa (mint Abd el-Latif el-Bagdadi alelnök és Mahmud Favzi külügyminiszter) is elkísért. A magyar sajtó ez alkalommal is címoldalon számolt be a rövid 


\section{Külïgyi Szemle}

látogatásról (Népszabadság, 1958; Népszava, 1958; Esti Hirlap, 1958), amelynek során az arab elnök néhány órát töltött a Ferihegyi repté ren, és ott tárgyalt a Münnich Ferene miniszterelnök által vezetett magyar kormánydelegációval.

E magas rangú látogatás előzménye, hogy 1957-ben a szudáni Mirgan Hamzani, ,az egyiptomi szociális és közmunkaügyi miniszter a nemrégiben Egyiptomban járt magyar szakszervezeti delegáció vezetỏjének kijelentette, hogy 1958 januárjában szivesen látogatna Magyarországra" (Magyar Nemzeti Levéltár, 1957c). Kádár utasította a kormányt a szudáni vezető meghívására és az afrikai delegáció költ ségeinek biztosítására.

Az előkészitő, építkező látogatások sorában még inkább meghatározó volt azonban Mahmud Favzi külügyminiszter meghívása 1958 januárjában, amiról a Sík Endre által jegyzett külügyminisztériumi elöterjesztés így szólt:

„Szịjártó Lajos kairói nagykövetünk látogatást tett dr. Mahmoud Fawzi egyiptomi külügyminiszternél, aki többek között elmon dotta, több egyiptomi miniszter tett már látogatást Magyaror szágon, s az itt látottakról valamennyien elismeróen nyilatkoz tak. Sajnálatát fejezte ki, hogy neki egy ilyen látogatásra még nem volt lehetősége, és megjegyezte: ha a sok vendégen kívül Magyarország elbír még egyet, ő szívesen eljön Budapestre, akár magánúton is. Kairói nagykövetünk biztosította arról, hogy magyarországi látogatásának nincs különösebb akadálya. Fawzi nagykövetünknek elmondotta, most igyekeznek Nasser elnököt meggyőzni, hogy tegyen látogatást Magyarországon" (Magyar Nemzeti Levéltár, 1958b).

A látogatás tehát megtörtént, s az eredményeképpen Magyaror szág 1958. február 13-án elismerte „az Egyiptomi Köztársaság és a Szíriai Köztársaság fúziójából létrejövô Egyesült Arab Köztársaság megalakulását" (Magyar Nemzeti Levéltár, 1958c).

Magyarország az 1950-es évek végére a nemzetközi diplomáciai élet aktív szereplőjévé vált. 1960-ra helyreállt a japán-magyar diplomáciai kapcsolat, együttmúködések születtek az Európai Szabadkereskedelmi Társulás (semleges) országaival. A közel-keleti és a 
latin-amerikai, valamint kiemelten a volt afrikai gyarmatterületeken újonnan függetlenné vált „fejlődő országokkal” való építkező külpolitikája vitális és eredményes volt: 1955-re 36, 1958-ra már 39 állammal kötött diplomáciai kapcsolatot (Győri Szabó, 2011, 266. o.).

A külügyi tárca szerepe - jelentős mértékben a karrierdiplomata és tudós Sík Endre miniszternek (1958-1961) köszönhetően - felértékelődött, a magyar diplomaták pedig egyre szakszerúbben végezték a munkájukat. A szervezeti struktúra átalakult, professzionálissá vált. Az 1947-es, Jónás Endre-féle Diplomáciai és nemzetközi jogi lexikont újrarendezték, és ismét megjelentették (Hajdú, 1967); Técsői Móricz Kálmán 1940-ben írt Külpolitika és külïigyi képzést követően megjelent a Külpolitikai és diplomáciai alapismeretek címú többkötetes „szolgálati” kiadvány, valamint Ustor Endre munkája, A diplomáciai kapcsolatok joga.

\section{Magyar-afrikai kapcsolatok 1960 után}

1960 októberében Kádár János New Yorkba utazott, ahol az ENSZ Közgyúlés bizalmát igyekezett megnyerni a szocialista ország 1956 os szerepével kapcsolatban. A nemzetközi közösségnek a magyar ügygyel kapesolatos érdeklődése akkorra már lankadt. 1961-ben John F. Kennedy lett az Amerikai Egyesült Államok elnöke, aki a Szovjetunióval ('igy Magyarországgal is) együttmúködőbb politikát képviselt, és a „magyarkérdésnek” a nemzetközi szervezet napirendjéról történő levételét támogatta. 1962-re rendeződni látszott a magyar-amerikai kapesolat, és 1963-ra az Egyesült Államok kezdeményezésére az ENSZ a magyar ügyet lezárta, a megbízottak befejezték a munkájukat. Ezt követően a budapesti kormány külpolitikai mozgástere jelentősen kibővült.

A kormány az addiginál is kezdeményezőbb, nyitottabb külpolitikába kezdett. Az általános utazási szabályok „enyhültek”: a szocialista relációban (a Szovjetunió kivételével) vízummentesen, piros útlevéllel lehetett kiutazni, míg Nyugatra - jóllehet még vízummal - az erre a célra rendszeresített kék útlevéllel, háromévente egyszer (némi valutával) volt szabad a mozgás. Enyhüiltek a beutazási szabályok is: 1964 


\section{Külïgyi Szemle}

től már elvben minden magyar követség adhatott ki Magyarországra szóló vízumot. A magyar állampolgárok utazási korlátozásai az 1970 es évektől lazultak tovább (Bencsik, 2002, 41. o.). A külügyi apparátus és igazgatás átalakult, a diplomaták képzése fejlődött, bővültt.

A magyar-afrikai kapesolatok az 1962-től kezdődő, második nagy periódusban a korábbinál is vitálisabbak lettek, amelyekkel kapcsolatban az alábbiakban Kállai Gyula, a Minisztertanács elnökhelyettesének 1962-es, majd 1966-os afrikai körútjait és Losonczi Pál, az Elnöki Tanács elnökének 1970-es útját, valamint az azokból fakadó külpolitikai hatásokat tekintjük át részletesebben.

\section{A Kállai-delegáció 1962-es körútja} és a Magyar Népközlársaság szerepe a szubszaharai Afrikában

A korszak legjelentősebb külpolitikai vonatkozása az afrikai reláció ban történt: a Kállai Gyula vezette delegáció 1962-ben afrikai körutat tett, amely azonban nem önmagában álló esemény volt, hanem egy diplomáciai építkezés eredménye. 1960-ban a Münnich-kabinet kormányküldöttet nevezett ki a Szomália függetlenségének kikiáltása alkalmából rendezett ünnepségen való részvételre, egyúttal döntött az afrikai ország elismerésérôl és a diplomáciai kapcsolatok felvételéről (Magyar Nemzeti Levéltár, 1960a). Hasonlóképpen döntés született a Mali Államszövetség, a Malgas, a Ghánai, a Togói, a Mali és a Szene gáli Köztársaság elismeréséről. Határozat született a Szakszervezetek Országos Tanácsa (SZOT) által meghívott algériai dolgozók munkába állításáról és szakképzéséről, valamint az Egyesült Arab Köztársaság és Magyarország vegyes bizottságának a létrehozásáról (Magyar Nemzeti Levéltár, 1960b). Ez utóbbi kapcsán a magyar kormány 1962 ben hitelegyezményt kötött magyar beruházási javak vásárlása céljából (Magyar Nemzeti Levéltár, 1961a). Még abban az évben oktatási, tudományos és kulturális egyezmény jött létre a Ghánai Köztársasággal, egyúttal döntöttek az afrikai ország köztársasági elnökének a meghívásáról (Magyar Nemzeti Levéltár, 1961b). Nkrumah elnök 1960 nyarán, a két hónapos kelet-európai körútja alkalmával tett látogatást Magyarországon (ld. még: Ginelli, 2018). 
Mindezek apróbb lépéseknek tekinthetőek az afrikai kétoldalú diplomáciai kapcsolatokban, azonban az előzményei annak az 1962-ben született komplex határozatnak, amely a Magyar Népköztársaságnak a Fekete-Afrikában várható politikai, gazdasági, kulturális és tájékoz tatási feladatairól rendelkezett ( Magyar Nemzeti Levéltár, 1962a). Ez a dokumentum már nem eseti, némileg ötletszerủ szinten foglalkozott az egyes afrikai kérdésekkel, hanem pragmatikus és átfogó irány elveket fogalmazott meg. Kimondta, hogy „adottságainknak és lehe tőségeinknek megfelelően fokozatosan kell növelnünk részvételünket Fekete-Afrika országainak segítésében”. „Guineába, Maliba, Gháná ba, Marokkóba, Nigériába és Tanganyikába" küldendő delegációkról is rendelkezett. A Mali Köztársasággal kötendő „kereskedelmi fizetési, hitel-, műszaki-segélynyúijtási és kulturális szerződésről", valamint etiópiai kereskedelmi kirendeltség felállitásáról döntött. További dip lomáciai kapcsolatok felvételét tűzte ki célul Tanganyikával, Nigériá val, Kongóval, Kenyával és Szenegállal. A Kádár János által 1962. június 14-én aláirt átfogó határozat a kor egyik legfontosabb ilyen tárgyú dokumentuma, a pragmatikusan építkező magyar (útkereső) külpolitika és afrikanisztika mérföldköve (Magyar Nemzeti Levéltár, 1962b).

Mindezek eredményeképpen a magyar kormány 1962-ben úgy döntött, hogy Kállai Gyulának, a Magyar Forradalmi Munkás-Paraszt Kormány elnökhelyettesének a vezetésével magas szintủ kormánydelegációt küldenek Nyugat- és Észak-Afrikába (Magyar Nemzeti Levéltár, 1962b). A kormányküldöttség, amelynek nagykövetek és más intézeti vezetők mellett tagja volt Incze Jenő külkereskedelmi miniszter, Szar ka Károly külügyminiszter-helyettes és Molnár János művelődésügyi miniszterhelyettes, 1962. december 1-jén utazott Afrikába (Magyar Nemzeti Levéltár, 1962c). A delegáció hét afrikai országba látogatott el: a Guineai, a Mali, a Dahomey, a Ghánai Köztársaságban, valamint Nigériában, az Algériai Demokratikus és Népi Köztársaságban, illetve a Marokkói Királyságban folytatott magas szintủ tárgyalásokat, írt alá megállapodásokat. A körútról a legtöbb magyar sajtóorgánum szinte naponta tudósított. A delegáció a hazaérkezését követően részletes javaslatcsomagot állított össze a kormány számára, amely - Kállai 


\section{Külïgyi Szemle}

Gyula megállapodásainak eredményeképpen - az 1963. augusztus 29 én kelt határozatában az alábbi javaslatokat hagyta jóvá, majd döntött a végrehajtásukról (Magyar Nemzeti Levéltár, 1963a):

- „Guinea és Ghána vonatkozásában építőanyag és szakember küildéséről

- a Mali Köztársaságban és Ghánában vízgazdálkodási technológia kiépítéséről

- Algériával kötendő gazdasági egyezményről, hitelnyúitásról

- afrikai vegyesvállalatok létrehozásáról

- belépést olyan nemzetközi szervezetekbe, amelyek a gyengén fejlett országokban erőteljes tevékenységet fejtenek ki

- az afrikai országok nyelveit beszélő szakemberek gyorsított kiképzéséről

- lobbitevénységről a multilaterális szervezetekben, afrikai országokba küldendô szakértők támogatását illetően

- a TESCO Külkereskedelmi Vállalat szakembereinek afrikai országokba küldéséről [Nem tévesztendő össze a hipermarketlánccal!]

- az 1963/64-es tanévre 137 ösztöndíjas hely felajánlásáról afrikai országoknak (és 1964/65-től új diákszállók felépítését követően e szám növeléséről)

- a Pécsi Orvostudományi Egyetemen egy angol oktatási nyelvû csoport létrehozásáról

- magyarországi egyetemi és főiskolai oktatás céljára Afrikába kiküildhető személyek nyilvántartásba vételérôl

- a Testnevelési Főiskolán guineai diákok angol nyelvú sportedző képzéséről

- a Marx Károly Közgazdaságtudományi Egyetemen nemzetközi ismeretek szak indításáról és ösztöndíjasok fogadásáról

- afrikai kulturális termékeknek a magyar közönséggel való megismertetéséről

- az Eötvös Loránd Tudományegyetem Bölcsészettudományi Karán Afrikanisztika Tanszék felállításáról 
- az Afrika Tudományos Intézet létrehozásának előkészítéséről, az MTA Afro-Ázsiai Kutató Csoportjának bevonásával kutatási program kidolgozásáról

- tudományos könyvkiadásról és könyvküldésről a Kulturális Kapcsolatok Intézete bevonásával

- zenetanárok Ghánába küldéséről, valamint afrikai kulturális szakemberek fogadásáról

- Nigériában és a Dahomey Köztársaságban nagykövetségek felállításáról"

- valamint a Guineai Köztársaság elnökének Kádár János által történő meghívásáról.

Kállai Gyula az afrikai útja során az ôt fogadó országokban átadta kormánya meghívását: Ahmed Ben Bella algériai, Hubert Maga dahomeyi, Sékou Ahmad Touré guineai elnöknek, Modibo Keïtának, Mali első elnökének, valamint a marokkói és a nigériai delegációk ve zetóinek (Magyar Nemzeti Levéltár, 1963b).

A Magyarországra ösztöndịjjal érkezett (az afrikai mellett ázsiai és dél-amerikai) diákok 1963-ban kezdték meg a tanulmányaikat - csupán érdekesség, hogy egészségügyi biztosítás hiányában a Miniszterta nács határozati utasítására a magyarországi tartózkodásuk idejére az egészségügyi miniszter rendezte az orvosi ellátásukat ( Magyar Nemzeti Levéltár, 1963c). Erre vonatkozóan további utalást találunk a Tudományos és Felsőoktatási Tanács „Szakemberek küllföldi képzésének és továbbképzésének, valamint küllföldiek Magyarországon történő képzésének helyzetéről” címú részletes jelentésében, amely szintén Kállai afrikai körútjából fakadó eredménynek tekinthető (Magyar Nemzeti Levéltár, 1963d). A dokumentum a magyar gazda ságban dolgozó szakemberek külföldön történő képzését és a küllföl di szakemberek magyarországi munkapiacra történő integrációját elemzi, és azzal kapcsolatosan fogalmaz meg terveket. Nemzetközi keretmegállapodást sürget a magyar szakemberek külföldön történő fogadásáról és az e szakterületre fordítható pénzügyi forrás megteremtéséről. Célként fogalmazza meg az állami adminisztrációban 


\section{Külïgyi Szemle}

dolgozók számára a küllöldi gyakorlat megszerzését. Megállapítja, hogy „törekedni kell minél több, a gyengén fejlett országokból jövő ösztöndíjas egyetemi hallgató fogadására. ... 1961/62-ben mindössze 60 fiatalt fogadtunk, az 1963/64-es tanévre viszont már 300, főként afrikai, ázsiai és latin-amerikai fiatalt várunk."

A magyar kormány 1964-ben kereskedelmi, valamint múszaki-tudományos megállapodást kötött Kenyával (Magyar Nemzeti Levéltár, 1964a), késóbb kulturális és tudományos megállapodás született a Mali Köztársasággal (Magyar Nemzeti Levéltár, 1964b).

Kállai és delegációjának algériai útja további eredményekkel is járt. 1964. november 1-jén, az algériai fegyveres felszabadító háború megindulásának 10. évfordulóján rendezett ünnepségen magyar párt-, kormány-, szakszervezeti és KISZ-delegáció vett részt. A küldöttség a helyi kormányzati és gazdasági szervezetek képviselői mellett Ben Bella elnökkel is találkozott, akivel - a Biszku Bélának írt tájékoztató jelentés szerint - a következő kérdésekről tárgyaltak: Algír főterére új szobrok magyarországi gyártásáról, Bella elnök személyi testőreinek a kiképzéséről, valamint magyar vetőmagok kísérleti gyártásáról (Ma gyar Nemzeti Levéltár, 1964c).

Hailé Szelasszié etióp császár 1964 szeptemberében látogatott Magyarországra - ez egyértelműen „a magyar diplomácia ... meghatározó eseményei között szerepelt” (Marsai, 2020, 29. o.). A látogatásáról a magyar sajtó is részletesen beszámolt, az országházi beszédét a honi lapok teljes terjedelmében közölték (Népszabadság, 1964). 1965 májusában pedig magyar kormánydelegáció utazott Etiópiába, hogy múszaki, tudományos, légügyi, valamint kulturális egyezményt kössön az Etióp Császársággal, amelyet Seyoum Haregot ideiglenes külügyminiszter írt alá (Magyar Nemzeti Levéltár, 1965). A találkozón, amelyen magyar szakemberek küldéséről, etióp ösztöndíjas diákok fogadásáról volt szó, egyrészt etióp részrôl megfogalmazódott az a kérés, hogy a magyar fél testnevelési főiskolát építsen Etiópiában, másrészt a ma gyar kormány 5 millió dolláros fejlesztési támogatási segélyt ajánlott fel az afrikai országnak - ez utóbbi végüil nem valósult meg (Magyar Nemzeti Levéltár, 1966a). 
Az 1960-as évek dinamikus külpolitikai nyitása a politikai, gaz dasági és tudományos élet vonatkozásai mellett számos egyéb területre is hatással volt. A folyamatosan erősödő afrikai kapcsolatoknak a haszonélvezője, de legalábbis az érintettje lehetett többek között az 1872-ben alakult Magyar Földrajzi Társaság, de azon kívül több felfedezô, hegymászó klub is, amelyek egyre növekvő érdeklődéssel fordultak az észak- és kelet-afrikai területek felé. Emellett a Fóvárosi Állat-és Növénykert is növelhette az afrikai kapcsolatait - annak felkeresését a Budapestre érkezett afrikai delegációk programjába is gyakran beleillesztették, így több állat (pl. nílusi vízilovak, oroszlánok) beszerzése is abban az időben valósulhatott meg. Az 1960-as években a Gödöllői Agrártudományi Egyetem afrikai diákjai is gyakran a budapesti állatkertben végezték a kutatásaikat, majd írtak szakdolgozatot a szüilőhazájuk állatvilágával kapcsolatos valamely témában.

Kiemelten kell említést tenni a Malév afrikai járatainak a megin dításáról is, amit az 1960-ban üzembe állított, már megfelelő hatótávolsággal $(4800$, ill. $6500 \mathrm{~km})$ rendelkező I1-18-as típusú repüilógép tette lehetôvé. Kezdetben azonban Budapestet csak az észak-afrikai államokkal kötötte össze közvetlen járat. A menetrend szerinti járatokon kívül a vállalat repülógépei az egyes afrikai államokkal való teher forgalom lebonyolításában is jelentős szerepet játszottak: elsősorban mezőgazdasági árucikkeket, élőállatot (naposcsibéket, tojójércéket, birkákat) szállítottak. Magyar repülőgép (a HA-MOH lajstromjelủ II18-as) egy kormányjárat során, 1966. február 11-én, a Budapest-Addis Abeba-Nairobi útvonalon repülte át először az Egyenlítőt (Zainkó, 1993, 13. o.). A szubszaharai afrikai országokkal történt gazdasági és kulturális együttmúködési megállapodásokkal együtt a légügyi egyez mények is megszülettek: 1958. március 20-án a magyar-egyiptomi, majd 1961. október 23-án a magyar-ghánai, a hetvenes évekig pedig még kilenc. 


\section{Külïgyi Szemle}

\section{A Kállai-delegáaió 1966-os úlja}

Az afrikai kapcsolatok további erósítése céljából 1966-ban ismét kor mányküldöttségről született elóterjesztés (Magyar Nemzeti Levéltár, 1966a). Péter János külüigyminiszter - akinek a hivatali ideje alatt sikerült az Amerikai Egyesült Államokkal rendezni az 1956 után alacsony szinten befagyott diplomáciai kapcsolatokat - döntése értelmében a magyar kormány ez alkalommal is Kállai Gyulát bízta meg a delegáció vezetésével és a megállapodások aláírásával. A küldöttség tárgyalásokat folytatott az Egyesült Arab Köztársaságban, az Etióp Császárságban, a Tanzániai Egyesült Köztársaságban, Kuvait Államban, az Indiai Köztársaságban és Cipruson.

A magyar sajtó e körútról (az időszakra jellemző erős külpolitikai érdeklődéssel) szintén folyamatosan tudósított. Kállaitól a repülőtéren Kádár János személyesen vett búcsút, amit az újságok címlapon közöltek (Népszabadság, 1966a). A delegáció első útja az Egyesült Arab Köztársaságba vezetett, ahol Kállai Zakaria Mohieddin miniszterelnökkel, majd Nasszer elnökkel tárgyalt; a beszédeit a hazai sajtó általában teljes terjedelemben közölte (Népszabadság, 1966a). Néhány nappal később a kormány Addisz-Abebában tárgyalt, ahol Kállait „az etiópiai uralkodó a Szentháromság-rend nagyszalagjával, feleségét a Sába királynője-renddel tüntette ki" (Népszabadság, 1966b). A delegáció Etiópiából Tanzániába folytatta útját: Kállai Julius Kambarage Nyerere társaságában részt vett a zanzibári forradalom évfordulójának ünnepén, ahol beszédet is mondott, majd kétoldalú tárgyalásokat folytatott. Ezt követően a küldöttség Kuvaitba és Indiába utazott. Hazatérve Kállai közel 50 oldalas elemző jelentést készített a körútról a Külüigyminisztérium számára, amellyel kapcsolatban a kormány az alábbi határozatokat hozta (Magyar Nemzeti Levéltár, 1966b):

- „folytatni kell a politikai, gazdasági és kulturális tevékenységet az újonnan felszabadult országokban, a magas szintú kapcsola tokat tovább kell erósíteni

- növelni kell a diákoknak és szakembereknek nyújtható anyagi és ösztöndíjas támogatások arányát 
- magyar-EAK gazdasági vegyes bizottságot kell létrehozni, idegenforgalmi megállapodást és légügyi megállapodást szükséges kötni

- Etiópiával kapcsolatban kísérleti gazdaságot kell létrehozni. sportcélú eszközöket átadni, ki kell dolgozni [az] etiópiai test nevelési főiskola támogatását, valamint segíteni az etióp állami népi együttes folklórmunkáját

- Tanzániával gépipari jellegű szakbizottságot szüikséges lét rehozni, TESCO-küldöttséget az országba küldeni, a Dar es Salaam-i Egyetemmel oktatócsere-programot elindítani, valamint légüigyi egyezményt létrehozni."

Hazánk 1962-ben létesített diplomáciai kapcsolatot Tanzániával, 1966-ban pedig megnyitotta az ottani küllképviseletét Dar es-Salaamban (Magyar Nemzeti Levéltár, 1966c). 1967-ben Magyarország keres kedelmi megállapodást kötött Elefántcsontparttal (Magyar Nemzeti Levéltár, 1967), a következő évben magyar gazdasági kormányküildött ség járt a Közép-afrikai Köztársaságban, Felső-Voltában, Szenegálban, Kamerunban és Mauritániában, ahol kereskedelmi egyezménye ket írtak alá (Magyar külpolitikai évkönyv, 1968, 87. o.).

A kommunista Magyarországnak 1970-re kiforrott Afrika-politikája lett, amelyet abban az időben elsősorban a két küilügyminiszter, Péter János és Puja Frigyes öltött (újra) formába. Az utóbbi a már hivatkozott munkájában (Puja, 1980) világos olvasatát adta annak a geopolitikai elképzelésnek, amelyet a kapitalista, illetve nyugati or szágok külpolitikájával szemben, egyfajta kontrapolitikaként kívántak megvalósítani. Tudatában voltak annak, hogy az afrikai országokkal való politikai kapcsolatok csak akkor lesznek erősek és kölcsönösek, ha azok jól megalapozott gazdasági, kulturális és tudományos együtt múködésekkel társulnak. Mindezt nagyon pontosan megtanulták az Afrikából hazatért delegációk tapasztalataiból: világosan látták, hogy a szubszaharai térség politikusainak csupán az ideológiai cél nem elegendő, számukra konkrét, kézzelfogható eredmények is kellenek a vitális kétoldalú kapcsolatok létesítéséhez. 


\section{Külïgyi Szemle}

A korabeli magyar politikatudomány és közgazdaságtan szakem berei, valamint a sajtó képviselői pedig megteremtették az igazoló el méleti hátterét is ennek az „ellendiplomáciának”. Egyebek között a Népszabadság és a Külpolitika rendszeresen közölte a magyar külügy Afrika-politikájának az értelmezését és az egyébként valóban kiemelkedő, hiánypótló gazdasági, kulturális eredményeit. 1962-ben megala pították a TESCO Nemzetközi Együttműködési Irodát (Internatio nal Technical and Scientific Cooperation and Trading Office), amely a közmunka, az oktatás, az egészségügy, a mezőgazdaság és a vízgazdálkodás terén kötött kétoldalú technológiai, oktatási és szakkép zési megállapodások koordinálásáért és végrehajtásáért volt felelős (Tarrósy, 2018, 92-111. o.). A tudás-és a technológiatranszfer a Magyarországról Afrikába irányuló exporttevékenység bővítésével járt. Az afrikaiak hosszú időn keresztüil számos magyar terméket ismertek közelről: például az Ikarus buszokat, a Globus konzerveket, a Ganz motorvonatokat vagy a Piros Arany ételízesítőt, a Hajdú mosógépe ket, az Elzett zárakat és lakatokat, illetve a MEDICOR orvostechnikai múszereit, készülékei. A magyar termékek ismertsége és elismertsége a szubszaharai afrikai térségben az 1970-es évek végére kiemelkedő lett. Magyar tudással épültek utak, vasutak és kórházak többek között Algériában, Líbiában, Marokkóban, de szakértőkkel volt jelen hazánk Angolában, Etiópiában, Kenyában és Tanzániában is.

\section{„Afrika-járás" 1970 után}

Losonczi Pál, a Magyar Népköztársaság Elnöki Tanácsának elnöke 1970 augusztusában és szeptemberében újabb afrikai körutat tett: az Egyesült Arab Köztársaságban Nasszer, Tanzániában Nyerere, Szudánban pedig Dzsafar Nimeri (Yaafar Numeiry) elnökkel tárgyalt (Magyar külpolitikai évkönyv, 1970, 156. o.). E látogatások során az egyes országokkal megerősödtek a „nem kapitalista úton” megkezdett együittmúködések, s lezárult az 1960 és 1970 közötti külpolitikai építkezés időszaka. Magyarországot 1967 őszén beválasztották az ENSZ Biztonsági Tanácsának nem állandó tagjai közé, 1968 tavaszán Fock 
Jenő személyében először tárgyalt magyar miniszterelnök NyugatEurópában. Hazánk külkereskedelmi forgalma élénk lett: az Afrikával kötött megállapodások eredményeként 1970-ben a behozatal értéke elérte a közel 440 millió, a kivitel pedig az 560 millió forintot.

Abban az évben a Magyar Népköztársaság már összesen 89 or szággal állt diplomáciai kapcsolatban, egy kivételével mindegyikkel - Afrikán belül 26-tal - nagyköveti szinten; 53 államban múködött nagykövetség, egyben követség, ötben pedig fökonzulátus. Ekkorra ,mintegy 80 fejlődő országgal tartott fenn kereskedelmi, gazdasági kapcsolatot; ezek közül több mint 30 az afrikai kontinensen fekszik. Közzïlük 18 országgal összesen 40 szerződés volt 1970-re érvényben" (Kisalföld, 1970). Minderról az 1968-ban indított Magyar külpolitikai évkönyv (a magyar diplomácia „almanachja”) részletesen is beszámolt.

Losonczi útjának hatására a külpolitikai építkezés folytatódott, és Afrika a magyar diplomácia kiemelt stratégiai terïlete lett. 1971-ben Rasdi Kavava (Rashidi Mfaume Kawawa) tanzániai miniszterelnök lá togatott Magyarországra, majd még abban az évben Losonczi Algé riába és Guineába utazott. 1973-ban Nigériában, Ghánában és Sierra Leonéban, 1975-ben pedig Líbiában és Szomáliában tárgyalt a kétoldalú kapcsolatok erôsitéséről. Az utak a hetvenes és a nyolcvanas években tovább folytatódtak, az elköteleződések mélyüiltek.

\section{Zárógondolatok}

Írásunkban - amely egy nagyobb, azonos tárgyú kutatásunk része azt vizsgáltuk, hogyan született meg hazánknak az afrikai országokkal való külkapcsolati rendszere az 1960-as, illetve részint az 1970-es években, és annak mentén miként szerveződött újjá a teljes magyar diplomácia. A hipotézisünk az volt, hogy e déli orientáció és az abból fakadó eredmények, tapasztalatok nem csupán termékenyítőleg hatottak a teljes magyar külügyi apparátusra, de az akkori sajátságos geopolitikai helyzetből adódóan alapjaiban határozták meg azt. Ebben külső és belső okok egyaránt közrejátszottak. Ilyen volt egyik oldalról Moszkva enyhülő külpolitikája, az elhidegülő szovjet-kínai viszony és 


\section{Külïgyi Szemle}

az egymás után függetlenné vált szubszaharai afrikai országok nyitási kísérlete; másik oldalról pedig a magyar külïgyi vezetés néhány rop pant felkészült, valóban vízióval rendelkező szakemberének az erôfe szítése. Ez így együttesen azt eredményezte, hogy a szovjet vezetés eltűrte az önálló útját járó magyar külügy nyitási törekvéseit, amelyek partnerekre találtak az azokkal egy időben önállósult baráti afrikai országokban.

Ahogy Szilágyi István is írta, a 1950-1989/1991 közötti időszak nem volt teljes mértékben kétpólusúnak tekinthető. Mint fogalmazott: a nemzetközi rendszer hatalmi-geopolitikai szempontból a töredezett multipolarizmus jegyeit mutatta, s ebbe a folyamatba a nagyhatalmak között a helyét kereső Magyarország pragmatikus lépéssel az afrikai kontinens irányába fordult, és ott ért el jelentős sikereket - ezzel viszont erősítve a többpólusosság elméletének a bizonyítékait (Szilágyi, 2013.)

A munkánkban azt kívántuk bizonyítani a némi történeti kitekin tést követően, hogy Magyarország, amely hosszú ideig nem rendelke zett szuverenitással, a külügyi függetlenségét éppen az afrikai reláci ók kialakításával, a diplomáciai apparátusának a szubszaharai térség (valamint az arab világ) egyes országaiban történt kiépítésével érte el.

Ez az építkező folyamat döntően az 1970-es évek végéig, de eleme iben egészen 1989-ig tartott. Azt követően a magyar rendszerváltás, a demokratikus intézmények újjáalakítása, majd hazánk NATO-hoz és az Európai Unióhoz való csatlakozása jelentett elsődleges prioritást. A magyar külïigyi fókusz afrikai dimenziója abban az időben háttérbe szorult: a Külüigyminisztériumban az önálló terüileti főosztály megszűnt, illetve a közel-keletivel olvadt össze; az afrikai kontinensen felépített követségi, nagykövetségi hálózat (és annak személyi állománya) drasztikusan lecsökkent; a kormányzati kapcsolatok minimálisra estek vissza. Ez egészen 2011-ig (a globális nyitás politikájának indításáig) tartott, illetve még inkább 2015-ig, amikor is a magyar kor mány az afrikai és a latin-amerikai gazdasági kapcsolatok erősítése céljából meghirdette a déli nyitás stratégiáját. Ennek az újraépítkező folyamatnak fontos pillanata volt 2019 márciusa, amikor Orbán Viktor 
miniszterelnök Praiába, a Zöld-foki Köztársaság fővárosába utazott: a rendszerváltás óta akkor lépett magyar miniszterelnök hivatalos állami látogatás keretében először az afrikai kontinens szubszaharai részébe (ugyanis 2016. május 31-én egy politikai-üzleti delegáció élén látogatout Egyiptomba a kormányfő). Szintén történelmi jelentőségű volt Áder János köztársasági elnök 2022 januári Ghánába és Kenyába tett útja: a rendszerváltás óta magyar államfő nem járt még e makrorégióban.

Az 1989-óta, különösen a 2015 óta eltelt időszak a kutatásunk külön tárgyát képezi. A jelen írásunk azonban annak a korábbi pragmatikus, építkező-újjáalakító munkának az összefoglalója, amelynek a kortárs folyamatok (jóllehet 30 év kihagyással) a folytatásának tekinthetőek. Végezetuil azt is meg kívánjuk jegyezni, hogy mára ez a képlet (mások mellett Pritz Pál és Sáringer János munkássága következtében) sokat gazdagodott, de ahogyan Békés Csaba bő 15 évvel ezelőtt fogalmazott: „a magyar küilpolitika 1968-1989 közötti időszakáról a levéltári források teljes feltárására alapozott és egyben a szintézis igényével megfogalmazott összefoglalót még nem lehet készíteni. A hatalmas mennyiségű forrásanyag feldolgozása és a fő tendenciák feltérképezése tekintetében is éveket vesz igénybe, a bilaterális kapcsolatok és más fontos területek, mint például a külgazdasági kapcsolatok feltárása pedig alighanem még a következó évtizedben is feladatot fog adni a kutatónak."(Békés, 2004, 140. о.)

Tanulmányunk ebbe a feltárási folyamatba kívánt bekapcsolódni: új szempontokkal gazdagítani a magyar külpolitika 20. századi történetének a feldolgozását, egyúttal ösztönzést nyújtani további hasonló kutatásokhoz. 


\section{Külïgyi Szemle}

\section{I rodalom.jegyzék}

Balogh Sándor (1982). A népi demokratikus Magyarország külpolitikája 1945-1947. Budapest: Kossuth Könyvkiadó.

Békés Csaba (2004). Magyar Külpolitika a szovjet szövetségi rendszerben, 1968-1989. In Gazdag Ferenc és Kiss J. László (szerk.), Magyar külpolitika a 20. században (133-172. o.)

Békés Csaba és Kecskés D., Gusztáv (2006). Aforradalom és a magyar kérdés az ENSZ-ben, 1956-1963. Budapest: Magyar ENSZ Társaság.

Bencsik Péter (2002). Útiokmányok, utazási lehetőségek és határforgalom a 20. századi Magyarországon. Regio, 13(2), 31-50.

Benkes Mihály (2006). Helyzelkép Fekele-Afrikáról. Politikai afrikaniszlikai ıanulmányok. Budapest: ELTE-MTTT.

Búr Gábor (2011). A szubszaharai Afrika lörlénele 1914-1991. Budapest: Kossuth Kiadó.

Esti Budapest (1956). A szudáni miniszterelnök távirata Hegedűs András elvtárshoz. 5(10).

Esti Hirlap (1956). A Magyar Népköztársaság elismerte a Szudáni

Köztársaságot. Hegedús András elvtárs távirata a Szudáni Köztársaság miniszterelnökéhez. 5(4).

Esli Hirlap (1957a). Kairo kormányzója a Fóvárosi Tanácsnál, 11(252), 1.

Esti Hirlap (1957b). Dieselvonaton utazik Győrbe Egyiptom közlekedési minisztere. $11(252), 1$.

Esti Hirlap (1958). Nasszer elnök átutazott Budapesten. 3(114).

Fage, John Donelly és Tordoff, William (2004). Afrika lörlénele. Budapest: Osiris Kiadó.

Ginelli Zoltán (2018). Hungarian Experts in Nkrumah's Ghana. Mezosfera. A letöltés ideje: 2021. május 10. http://mezosfera.org/hungarian-expertsin-nkrumahs-ghana/.

Gyarmati György (2013). A Rákosi-korszak. Rendszerváltófordulatok évlizede Magyarországon, 1945-1956. Budapest: ÁBTL-Rubicon.

Győri Szabó Róbert (2011).A Magyar külpolitika lörlénele 1848-lól napjainkig. Budapest: Helikon.

Hajdú Gyula (1967). Diplomáciai és nemzelközi jogi lexikon. Budapest: Akadémia Kiadó.

Herczegh Géza (1987). Magyarország kïlpolitikája 896-1919. Budapest: Kossuth Kiadó. 
Horváth Jenő (1941). Magyar diplomácia, magyar diplomaták. Budapest: Szent István Társulat.

J. Nagy László (2017). Magyarország és az arab világ 1947-1989. Világlörténel, $9(41), 341$.

Kisalföld (1970). Hazánk gazdasági kapcsolatai afrikai országokkal. 15(26), 193.

Külkereskedelem (1957). A magyar kereskedelmi kamara piackutató főosztálya közleményei. 1(2), 16-17.

Magyar Közlöny (1956a). Nyilatkozat a Szudáni Köztársaság független államiságának elismeréséról. (2).

Magyar Közlöny (1956b). Zágor György nagykövet kinevezéséről a Szudáni Köztársaságba. (18).

Magyar Közlöny (1957). A Népköztársaság Elnöki Tanácsának 1957. évi 1-5. számú határozata a Magyar Népköztársaság kairói követségének nagykövetségi rangra való emeléséról. (66).

Magyar külpolitikai évkönyv (1968). A Magyar Népközlársaság nemzetközi kapcsolatainak és külpolitikai tevékenységeinek eseménynaplója. Budapest: Kossuth Könyvkiadó.

Magyar külpolitikai évkönyv (1970). Közös közlemény Losonczi Pálnak, az Elnöki Tanács elnökének az Egyesült Arab Közlársaságban lörtént lálogatásáról. Budapest: Kossuth Könyvkiadó.

Magyar Nemzel (1956a). Hegedús András távirata a Szudáni Köztársaság miniszterelnökéhez. 12(4).

Magyar Nemzel (1956b). A magyar-szudáni kereskedelmi kapcsolatok kiszélesítéséról beszélt a szudáni kereskedelmi miniszter Budapesten. 12(120).

Magyar Nemzeti Levéltár (1956a). MNL-OL-XIX-A-83-b 32413275/19563241/1956. A magyar állampolgároknak a népi demokratikus országokba való kiutazásának megkönnyítéséről.

Magyar Nemzeti Levéltár (1956b). MNL-OL-XIX-A-83-b 3002/1956. A Szudáni Köztársaság független államként való elismeréséról.

Magyar Nemzeti Levéltár (1956c). MNL-OL-XIX-A-83-b 3106 3140/19563139/1956. Magyar-szudáni diplomáciai kapcsolatok felvétele. Magyar Nemzeti Levéltár (1957a). MNL-OL-XIX-A-83-b 30513130/19573115/1957. Hivatalos külföldi utazások engedélyezése.

Magyar Nemzeti Levéltár (1957b). MNL-OL-XIX-A-83-b 31313199/19573175/1957. Kairói követség nagykövetségi rangra való emelése. 


\section{Külïgyi Szemle}

Magyar Nemzeti Levéltár (1957c). MNL-OL-XIX-A-83-b 30013030/19583003/1957. Egyiptomi szociális és közmunkaügyi miniszter Magyarországra való meghívása.

Magyar Nemzeti Levéltár (1958a). MNL-OL-XIX-A-83-b 31913245/19583245/1958. A szudáni kereskedelmi miniszter meghívása.

Magyar Nemzeti Levéltár (1958b). MNL-OL-XIX-A-83-b 3031 3090/19583037/1958. Egyiptomi külügyminiszter meghívása Magyarországra.

Magyar Nemzeti Levéltár (1958c). MNL-OL-XIX-A-83-b 3031 3090/19583048/1958. Egyesült Arab Köztársaság elismerése.

Magyar Nemzeti Levéltár (1960a). MNL-OL-XIX-A-83-b 31513200/19603169/1960. Szomália függetlenségének kikiáltása alkalmából rendezendő ünnepségekre kormányküldött kijelöléséről, valamint Szomália elismeréséról és a diplomáciai kapcsolatok felvételéról.

Magyar Nemzeti Levéltár (1960b). MNL-OL-XIX-A-83-b 3076 3110/19603110/1960. Delegáció küldéséről az Egyesült Arab Köztársaságba vegyes bizottsági tárgyalások folytatására.

Magyar Nemzeti Levéltár (1961a). MNL-OL-XIX-A-83-b 30013070/19613052/1961. Egyesült Arab Köztársasággal kötött hitelegyezmény ratifikálása.

Magyar Nemzeti Levéltár (1961b). MNL-OL-XIX-A-83-b 32013250/19613203/1961. A magyar-ghanai kulturális egyezmény jóváhagyásáról.

Magyar Nemzeti Levéltár (1962a). MNL-OL-XIX-A-83-b 31713215/19623177/1962. Magyar Népköztársaság politikai, gazdasági, kulturális feladatai Fekete-Afrikában.

Magyar Nemzeti Levéltár (1962b). MNL-OL-XIX-A-83-b 32713349/19623340/1962. Afrikába utazó kormánydelegáció útjának előkészítése.

Magyar Nemzeti Levéltár (1962c). MNL-OL-XIX-A-83-b 32713349/19623285/1962. Nyugat-Afrikába küldendő kormánydelegáció.

Magyar Nemzeti Levéltár (1963a). MNL-OL-XIX-A-83-b 33213380/19633334/1963. Kállai Gyula vezetésével Afrikában járt kormányküildöttség útjából eredó javaslatok jóváhagyása.

Magyar Nemzeti Levéltár (1963b). MNL-OL-XIX-A-83-b 30013055/19633027/1963. Az 1963. évi államföi és kormánydelegációk, és hivatalos egyéni kiküldetésekről, valamint hasonló küllföldi delegációk fogadásáról. 
Magyar Nemzeti Levéltár (1963c). MNL-OL-XIX-A-83-b 32813320/19633289/1963. Az afrikai, ázsiai és dél-amerikai diákok orvosi ellátásáról.

Magyar Nemzeti Levéltár (1963d). MNL-OL-XIX-A-83-b 33813430/19633410/1963. A szakemberek küllföldi képzése és a küllföldiek Magyarországon történó képzésének helyzete.

Magyar Nemzeti Levéltár (1964a). MNL-OL-XIX-A-83-b 32813330/19643303/1964. Kenyával kereskedelmi és múszaki-tudományos egyezmény kötése.

Magyar Nemzeti Levéltár (1964b). MNL-OL-XIX-A-83-b 3331 3365/19643364/1964. Mali Köztársasággal kulturális és tudományos megállapodás.

Magyar Nemzeti Levéltár (1964c). MNL-OL-XIX-A-83-b 34463485/19643446/1964. A magyar-algériai kapcsolatokról.

Magyar Nemzeti Levéltár (1965). MNL-OL-XIX-A-83-b 31913240/19653221/1965. Magyar-etióp tárgyalások.

Magyar Nemzeti Levéltár (1966a). MNL-OL-XIX-A-83-b 30013045/19663025/1966. Kormányküldöttség utazása az Egyesült Arab Köztársaságba, Etiópiába, Tanzániába, Kuwaitba és Indiába.

Magyar Nemzeti Levéltár (1966b). MNL-OL-XIX-A-83-b 3046 3090/19663070/1966. Kállai Gyula vezetésével az Egyesült Arab Köztársaságban, Etiópiában, Tanzániában, Kuwaitban, Indiában és Cipruson járt kormányküldöttség útjáról szóló jelentés.

Magyar Nemzeti Levéltár (1966c). MNL-OL-XIX-A-83-b 3295 3340/19663315/1966. Tanzániában külképviselet létrehozása.

Magyar Nemzeti Levéltár (1967). MNL-OL-XIX-A-83-b 30963155/19673154/1967. Elefántcsontpart Köztársasággal kötött kereskedelmi megállapodás.

Magyar Tudomány (1967). A párt IX. kongresszusa után. 74(1), 3.

Marsai Viktor (2019). A magyar-etióp diplomáciai kapcsolatok felvétele. Külïgyi Szemle, 18(4), 48-66.

Marsai Viktor (2020). Az utolsó császár Magyarországon - Hailé Szelasszié 1964-es látogatása. Afrika Tanulmányok / Hungarian Journal of African Studies, 14(3-4), 29-46.

Meebelo, Henry S. (1986). African Prolelarians and Colonial Capilalism. Zambia: Kenneth Kauda Foundation. 


\section{Külïgyi Szemle}

Népszabadság (1958). Az Egyesült Arab Köztársaság és a Magyar

Népköztársaság közötti kapcsolatok mind barátibbá válnak, mondotta a Budapesten átutazó Nassaer elnök. 16(102).

Népszabadság (1964). I. Hailé Szelasszié császár Budapesten. 12(222).

Népszabadság (1966a). Kállai Gyula megkezdte afrikai és ázsiai körútját. 24(27).

Népszabadság (1966b). Kállai Gyula Addisz Abebában. A magyar kormányfó Hailé Szelasszié császárnál. 24(33).

Népszava (1956a). Hegedűs András elvtárs távirata a Szudáni Köztársaság miniszterelnökéhez. 84(4).

Népszava (1956b). Megszabadultunk az imperialista igától. Beszélgetés Ibrahim el Mufti szudáni kereskedelmi miniszterrel. 84(120).

Népszava (1958). Kapesolataink mind barátibbá válnak. $86(101)$.

Net.jogtar (é. n.). 1918. évi V. néptörvény az önálló magyar külügyi igazgatásról. A letöltés ideje: 2021. május 12. https://net.jogtar.hu/ getpdf?docid $=91800205$. TV\&targetdate $=$ \&print Title $=1918 .+\% \mathrm{C} 3 \% \mathrm{~A} 9 \mathrm{vi}^{+}$ V. + n\%C3\%A9pt\%C3\%B6rv\%C3\%A9nv\&referer $=1000$ ev.

Pritz Pál (2006). Magyar külpolitikai gondolkodás a 20. században. In

Pritz Pál, Sipos Balázs és Zeidler Miklós (szerk.), A VI. Hungarológiai Kongresszus szimpóziumának anyaga. A letöltés ideje: 2021. május 18. http://real-eod.mtak.hu/1841/1/Magyar kulpolitika_20_szazad.pdf.

Puja Frigyes (1980). Magyar külpolitika. Budapest: Kossuth Könyvkiadó.

Romsics Ignác (2003). Magyarország lörlénele a XX. században. Budapest:

Osiris Kiadó.

Szélinger Balázs (2008). Magyarország és Etiópia. Formális és informális kapcsolatok a 19. század második felétôl a II. világháborúig. Doktori értekezés. Szeged: Szegedi Tudományegyetem. A letöltés ideje: 2021. augusztus 21. http://doktori.bibl.u-szeged.hu/id/eprint/1212/1/ dissertatio_SzB.pdf.

Szilágyi István (2013). Geopolitika. Pécs: Publikon Kiadó.

Tarrósy István (2018). Hungarian Foreign Policy Towards Africa During Communism and in the Post-Soviet Era. Twentielh Century Communism, 15, 92-111.

Újvári Gábor (2017). A szuezi válság és Magyarország 1956. Budapest: Veritas-Magyar Napló.

Vámos Péter (2017). Baráti segítség és önerőre támaszkodás. Magyar geo

fizikus expedíció Kínában, 1956-1962. Történelmi Szemle, 59(1), 47-75. Zainkó Géza (1993). Ferihegyi dátumok. Aero História, (11). 